\title{
Faktor Ibu yang Mempengaruhi Partus Abnormal di RSUD Arifin Achmad Provinsi Riau
}

\author{
Maternal Factors that Influence Abnormal Parturition at Arifin Achmad \\ Hospital Riau Province
}

\section{Nurlisis}

\author{
Program Studi Magister Ilmu Kesehatan Masyarakat STIKes Hang Tuah Pekanbaru
}

\begin{abstract}
ABSTRAK
Partus Abnormal menunjukkan adanya faktor penyulit atau komplikasi persalinan. Data di RSUD Arifin Achmad jumlah persalinan 2981 kasus, dimana jumlah persalinan dengan vakum ekstrasi sebanyak 96 kasus $(9,17 \%)$, SC sebanyak 407 kasus (8,8\%) dan letak sungsang 82 kasus (12,97\%), kasus partus abnormal menepati urutan terbanyak. Penelitian ini bertujuan untuk diketahuinya hubungan faktor-faktor dari Kondisi kehamilan, Jarak kelahiran sebelumnya, Kadar Hb, Kondisi Ketuban, Tekanan Darah, Tempat tinggal, Cara Datang ke RS, Umur, Paritas, Pekerjaan dan Pendidikan dengan partus Abnormal. Jenis penelitian yang digunakan adalah observasional. Jenis desain penelitian yang digunakan adalah studi kasus kontrol (Case Control). Populasi penelitian ini adalah seluruh ibu yang melahirkan di RSUD Arifin Achmad Pekanbaru. Besarnya sampel penelitian ditentukan dengan memperhatikan Odds Ratio (OR) hasil beberapa penelitian terdahulu tentang beberapa faktor yang mempengaruhi persalinan abnormal. Analisis data dilakukan secara univariat, bivariat dan multivariat dengan metode regresi logistic dengan program komputerisasi. Hasil penelitian ini adalah, Kondisi Kehamilan (OR : 2,77 ; $95 \% \mathrm{Cl}: 1,66-$ 4,60), Kadar $\mathrm{Hb}$ (OR : 9,59 ; 95\% Cl : 4,26 - 21,59), Tekanan Darah (95\% Cl : 0,09-0,31), Tempat Tinggal ( 95\% Cl : 3,1711,18), Cara Datang ke RS (95\% Cl : 1,78 - 4,6), Umur (95\% Cl : 1,2 - 3,32), Pekerjaan (95\% Cl : 1,88 - 4,78), Pendidikan $(95 \% \mathrm{Cl}: 1,07-2,68)$. Kesimpulan dari penelitian ini bahwa variabel dominan yang berhubungan dengan partus abnormal adalah Kadar Hemoglobin ( $\mathrm{Hb}$ ) dan tidak ada data yang coufonding. Saran bagi perempuan yang sudah tidak menginginkan hamil lagi, disarankan untuk menggunakan alat kontrasepsi yang efektifitasnya tinggi (alat kontrasepsi mantap).
\end{abstract}

Kata Kunci: partus abnormal, kondisi kehamilan, $\mathrm{Hb}$ ibu, RSUD Arifin Achmad

\section{ABSTRACTS}

Abnormal Pertus indicate the presence of complicating factors or complications of childbirth. Data at Arifin Achmad 2981 the number of labor cases, where the number of deliveries by vacuum extraction of as many as 96 cases (9.17\%), SC as many as 407 cases (8.8\%) and breech position 82 cases (12.97\%), keeping the case the highest order. This study aims to know the factors associated with abnormal parturition the condition of pregnancy, birth spacing before, the levels of Hb, Conditions Membranes, Blood Pressure, Housing, How to come to the hospital, Age, Parity, Employment, Education. Method: this was an observational research using case control study. The number of samples are 245 cases and using 245 cases as controls. Data analyzing was performed using univariate, bivariate and multivariate logistic regression method by program conputer. The results of this study is, the condition of pregnancy (95\% CI: 1.66 to 4.60), Hb levels (95\% CI: 4.26 to 21.59$)$, Blood Pressure (95\% CI: 0.09 to 0.31), residence (95\% CI: 11.18 to 3.17), How Come RS (, 95\% CI: 1.78 to 4.6), age (95\% Cl: 1.2 to 3.32), Employment (95\% CI: 1.88 to 4.78), education (95\% CI: 1.07 to 2.68). The conclusion of this study that the dominant variables associated with abnormal parturition is Hemoglobin Levels (Hb). Advice for mothers who have no desire to get pregnant again, it is advisable to use a high effectiveness of contraception (intrauterine device steady).

Keyword: Abnormal Pertus, condition of pregnancy, the levels of Hb mother, Arifin Achmad RSUD

\section{PENDAHULUAN}

Partus Abnormal merupakan prosedur kebidanan dimana tindakan aktif diambil oleh penolong untuk menyelesaikan persalinan, apabila proses persalinan tidak dapat berjalan secara normal. Partus abnormal adalah persalinan yang tidak dapat berjalan normal secara spontan atau tidak berjalan sendiri, oleh karena terdapat indikasi adanya penyulit yaitu kala II lama, partus tak maju, gawat janin, hidromion, plasenta previa, preeklamsi berat/eklamsi dan malposisi, sehingga persalinan dilakukan dengan memberikan tindakan menggunakan alat bantu. Partus abnormal dilakukan jika kelahiran spontan diduga berisiko lebih besar pada ibu atau anak dari pada tindakannya (Rusyidi, 2004).

Hasil SDKI 2007 melaporkan bahwa seluruh persalinan, $28 \%$ ibu mengalami perdarahan, eklamsia sebesar $24 \%$, infeksi sebesar $11 \%$, komplikasi sebesar $8 \%$, partus macet sebesar $5 \%$, trauma obstetric $5 \%$ dan lain-lain $11 \%$. Data yang diporoleh dari Rekam medik RSUD Arifin Achmad Provinsi Riau tahun 2010 didapatkan data jumlah persalinan 2981 kasus, dimana jumlah persalinan dengan vakum ekstrasi sebanyak

Alamat Korespodensi: Nurlisis, STIKes Hang Tuah Pekanbaru, HP: 08127661777, Email: isis.webby@yahoo.com 
96 kasus $(9,17 \%)$, SC sebanyak 407 kasus $(8,8 \%)$ dan letak sungsang 82 kasus (12,97\%), kasus menepati urutan terbanyak di RSUD Arifin Achmad.

Melihat jumlah partus abnormal yang cukup besar, dan faktor-faktor yang berhubungan dengan partus abnormal sangat banyak, maka peneliti ingin mengetahui bahwa faktor-faktor apa yang berhubungan terhadap partus abnormal. Tujuan penelitian ini adalah untuk membuktikan faktor-faktor yang berhubungan dengan partus abnormal di RSUD Arifin Achmad Prov. Riau.

\section{METODE}

Jenis penelitian yang digunakan adalah observasional, dengan jenis desain studi kasus kontrol. Lokasi penelitian ini dilakukan di RSUD Arifin Achmad Provinsi Riau. Populasi dalam penelitian ini adalah seluruh ibu yang melahirkan di RSUD Arifin Achmad Pekanbaru. Subjek dalam penelitian ini adalah ibu yang melahirkan terdata tahun 2010 sebanyak 245 dengan partus abnormal dan 245 dengan persalinan normal. Besarnya sampel penelitian ditentukan dengan memperhatikan Odds Ratio (OR) hasil beberapa penelitian terdahulu tentang beberapa faktor yang mempengaruhi persalinan abnormal dengan alfa $5 \%$ dan beta $10 \%$. Teknik pengambilan sampel dengan cara systematic random sampling dan pengumpulan data secara sekunder. Analisis data dilakukan secara multivariat dengan metode regresi logistik ganda.

\section{HASIL}

Hasil uji bivariat terhadap 11 variabel, berhubungan dengan Partus Abnormal adalah variabel Kondisi Kehamilan, Jarak Kelahiran, Kadar $\mathrm{Hb}$, Tekanan Darah, Kondisi Ketuban, Tempat Tinggal, Cara datang ke RS, Umur Ibu, Paritas, Pekerjaan dan Pendidikan ( Lihat Tabel 1).

Ibu yang Kondisi kehamilan beresiko melahirkan dengan Partus Abnormal 2 kali dibandingkan ibu yang tidak mengalami kondisi kehamilan bermasalah. Ibu yang memiliki jarak kelahiran $<2 \&>5$ tahun lebih beresiko Partus Abnormal 1,5 kali dibandingkan ibu yang memiliki jarak kelahiran $\geq 2-5$ tahun. Kadar $\mathrm{Hb}$ ibu $<11$ gr\% lebih beresiko partus Abnormal 10 kali dibandingkan ibu yang memiliki $\mathrm{Hb}>11 \mathrm{gr} \%$. Ibu yang memiliki Tekanan Darah tinggi/ hipertensi lebih beresiko partus Abnormal 0,5 kali dibandingkan ibu yang memiliki tekanan darah normal. Ibu yang mengalami Ketuban Pecah dini lebih beresiko partus Abnormal 2 kali dibandingkan ibu yang memiliki tekanan darah normal. Ibu yang Tempat Tinggal dari luar kota lebih beresiko partus Abnormal 2 kali dibandingkan ibu yang Tempat Tinggalnya di dalam kota. Ibu yang datang dengan rujukan lebih beresiko partus
Abnormal 2 kali dibandingkan ibu yang datang tanpa rujukan normal. Ibu yang termasuk kategori umur beresiko (umur $<2$ tahun dan umur $>35$ tahun) lebih beresiko mengalami Partus Abnormal 2 kali dibandingkan ibu yang tidak termasuk kategori umur yang beresiko (umur 20 tahun sampai dengan umur 35 tahun). Ibu yang termasuk kategori paritas beresiko (paritas 0 dan paritas $>4$ ) lebih beresiko Partus Abnormal 2 kali dibandingkan ibu yang tidak termasuk kategori paritas yang beresiko (paritas 0 dan paritas. ibu yang bekerja lebih beresiko melahirkan dengan Partus Abnormal 2 kali dibandingkan ibu yang tidak bekerja. Ibu yang berpendidikan rendah (tidak sekolah, pendidikannya SD, SMP) lebih beresiko melahirkan Partus Abnormal 2 kali dibandingkan ibu yang pendidikannya Tinggi (SMA dan PT).

Hasil multivariat didapat variabel yang berhubungan adalah variabel Kondisi kehamilan, Kadar Hb, Tekanan Darah, Tempat Tinggal, Cara datang ke RS, Umur Ibu, Pekerjaan dan Pendidikan (Lihat Tabel 2). Tidak terdapat counfonding antarra variabel.

Hasil analisis didapatkan Odds Ratio (OR) dari variabel $\mathrm{Hb}$ ibu saat hamil adalah 9,594 artinya ibu dengan $\mathrm{Hb}<11$ gr\% lebih beresiko akan Partus Abnormal 10 kali lebih tinggi dibandingkan ibu yang $\mathrm{Hb}>11$ gr\% setelah dikontrol Variabel Kondisi Kehamilan, Hb Ibu Saat Hamil, Tekanan Darah, Tempat Tinggal Cara Datang Ke RS, Umur Ibu, Paritas, Pekerjaan, Pendidikan. Secara sama dapat diinterprestasikan untuk variabel yang lain. Semakin besar nilai exp (B) berarti semakin besar pengaruhnya terhadap variabel dependen yang dianalisis. Hal ini berarti $\mathrm{Hb}$ ibu paling besar pengaruhnya terhadap kejadian Partus Abnormal.

\section{PEMBAHASAN}

\section{Kondisi Kehamilan}

Kondisi kehamilan resiko tinggi merupakan faktor risiko yang sangat berpengaruh terhadap persalinan abnormal. Kondisi kehamilan risiko tinggi ditandai dengan beberapa hal antara lain riwayat obstetric yang jelek seperti abortus, lahir mati, pernal mengalami partus abnormal, keadaan yang tidak sehat pada proses reproduksi seseorang kemungkinan dapat menyebabkan penyulit atau komplikasi.

Hasil penelitian didapat Kondisi kehamilan bermasalah menunjukkan adanya komplikasi kehamilan dan persalinan yang merupakan indikasi untuk dilakukan persalinan dengan tindakan atau partus abnormal. Adanya keluhan selama kehamilan merupakan pengaruh terjadinya komplikasi persalinan pada sampel seperti kehamilan letak sungsang, letak lintang, anemia berat, PEB/ Eklamsi. Hal ini juga terkait dengan Kadar $\mathrm{Hb}$, semakin rendah kadar $\mathrm{Hb}$ ibu 
memungkinkan kondisi masa kehamilan bermasalah dan berlanjut ke persalinan.

Hal ini sejalan dengan penelitian Kusuma (2004) Hasil analisis menunjukkan bahwa ada hubungan signifikan antara kondisi kehamilan risiko tinggi dengan kejadian persalinan dengan partus dengan tindakan $(p=0,0001)$. Ibu dengan kondisi kehamilan risiko tinggi mempunyai risiko sebesar 3,46 kali mengalami persalinan dengan tindakan daripada ibu dengan kondisi kehamilan risiko rendah.

\section{Kadar Hb}

Anemia pada ibu hamil adalah suatu keadaan yang menunjukan kadar haemoglobin $(\mathrm{Hb})$ didalam darah lebih rendah dari nilai normal yaitu $11 \mathrm{gr} \% \mathrm{ml}$. Kadar $\mathrm{Hb}$ merupakan salah satu indikator status gizi seseorang. Kondisi kadar $\mathrm{Hb}$ yang rendah (anemia) terutama pada ibu hamil sangat berpengaruh terhadap kondisi janin yang dikandung dan proses persalinan yang dialami. Kasus persalinan tindakan yang ditemukan memang sebagian besar oleh karena indikasi kala II lama dan Partus tak maju. Kadar $\mathrm{Hb}$ pada ibu hamil, sampai pada bulan-bulan terakhir dan saat mendekati proses persalinan mempengaruhi kerja otot-otot alat reproduksi yaitu otot uterus, otot panggul dan ligamen. Hal ini mengakibatkan ibu tidak mempunyai kekuatan his (power adekuat), sehingga menyebabkan pembukaan jalan lahir tidak optimal yang akhirnya proses persalinan mengalami kesulitan. Hal ini merupakan komplikasi persalinan yangg sering terjadi oleh karena itu, untuk mnyelamatkan bayi dan ibu perlu dilakukan persalinan dengan menggunakan alat seperto vacum ekstrasi.

Kadar $\mathrm{Hb}$ rendah juga menyebabkan pengangkutan oksigen dalam organ-organ pernapasan kurang, sehingga kekuatan pernafasan pada saat persalinan lemah yang mengakibatkan proses persalinan terhambat karena tenaga ibu melemah (mother exhausted).

Menurut Taber (2002) anemia jarang menimbulkan kedaruratan akut selama kehamilan, namun setiap masalah kegawatan dapat diperberat oleh anemia yang telah ada. Seperti halnya pada proses persalinan, kondisi kala II lama atau partus tak maju, akan diperberat dengan adanya anemia.

\section{Pekerjaan}

Menurut Depkes RI (2003) yang menyatakan bahwa pekerjaan mempengaruhi status sosial ekonomi dan ini akan berpengaruh dalam mendapatkan pelayanan antenatal yang adekuat dan pemenuhan gizi. Ibu yang bekerja dapat menambah pendapatan rumah tangga sehingga dapat memperoleh pelayanan kesehatan selama hamil secara rutin dan cukup didalam pemenuhan gizi sehingga dapat melahirkan dengan berat badan normal dibandingkan hanya suami yang bekerja dalam memenuhi kebutuhan rumah tangga.
Hal ini sejalan dengan peneliti karena dengan ibu yang bekerja akan membantu perekonomian keluarga, sehingga kebutuhan ibu selama hamil dapat terpenuhi seperti pemenuhan makanan-makanan yang bergizi, dan pemeriksaan kehamilan secara teratur oleh tenaga kesehatan dengan demikian bayi didalam kandungan ibu akan sehat dan lahir dengan berat badan yang normal nantinya.

\section{Cara Datang ke RS}

Cara datang dengan rujukan merupakan faktor yang berpengaruh terhadap partus Abnormal. Persalinan yang ditolong dengan vacum ekstrasi merupakan dari riwayat persalinan lama yang dikiriom (rujuk) oleh bidan, karena tidak berhasil usaha untuk partus normal, biasanya bidan merujuk pasien ke RSUD dan ini kebanyakan pasien yang bersal dari luar kota. Cara mengurangi rujukan pasien karena kala II lama atau partus macet serta riwayat obstetric lainnya, dengan cara memantau mulai kehamilan dengan melakukan ANC minimal 4 kali selama kehamilan yaitu 1 kali pada semester I, 1 kali pada semester II dan 2 kali pada semester III.

\section{Tempat Tinggal}

Peneliti menyimpulkan bahwa pasien persalinan dengan tindakan karena indikasi partus dengan vacum sebagian besar bertempat tinggal di luar kota. Hal ini juga dikarenakan RSUD Arifin Ahmad Pekanbaru merupakan rumah sakit rujukan yang menerima pasien-pasien persalinan dengan komplikasi atau penyulit yang sebagian besar dari luar kota Pekanbaru. Meskipun pada penelitian ini faktor cara datang dengan rujukan tidak berpengaruh terhadap persalinan tindakan, namun pada analisis perbedaan proporsi dapat dilihat bahwa 56,9 \% kasus datang dengan cara dirujuk.

Dengan demikian pasien yang mengalami komplikasi dan memerlukan tindakan pada persalinannya memang lebih banyak berasal dari luar kota yang mengalami komplikasi dan telah dilakukan upaya rujukan. Sedangkan pasien yang termasuk risiko tinggi (mempunyai riwayat persalinan sulit) sebelumnya, meskipun dari luar kota namun telah mempunyai kesadaran yang baik langsung datang ke RS.

Penelitian ini juga konsistensi dengan hasil penelitian Snewe dan Sulistiyowati (2001) yang menyimpulkan bahwa ibu yang tinggal di daerah pedesaan mempunyai risiko untuk terjadi komplikasi persalinan sebesar 2,1 kali $(95 \%$ I : 1,09-4,02) dibandingkan dengan ibu yang tinggal di daerah perkotaan. Komplikasi persalinan dalam penelitian ini meliputi partus lama, perdarahan, infeksi dan preeklamsi yang semua ini merupakan indikasi utama dilakukannya persalinan dengan tindakan. Faktor daerah dan kawasan sebenarnya berkaitan dengan ekonomi, pendidikan dan sarana yang tersedia. Jarak 
suatu wilayah juga membatasi kemampuan dan kemauan wanita untuk mencari pelayanan kesehatan.

\section{Umur Ibu}

Usia reproduksi optimal bagi seorang ibu adalah antara umur 20-35 tahun. Di daeah atau diatas usia tersebut akan meningkatkan risiko kehamilan dan persalinannya. Umur ibu kurang dari 20 tahun menunjukkan rahim dan panggul ibu belum berkembang secara sempurna karena wanita pada usia ini masih dalam masa pertumbuhan sehingga panggul dan rahim masih kecil. Disamping itu, usia diatas 35 tahun cenderung mengakibatkan timbulnya masalahmasalah kesehatan seperti hipertensi, DM, anemia, TB paru dan dapat menimbulkan persalinan lama dan perdarahan pada saat persalinan serta risiko terjadinya cacat bawaan pada janin.

Prognosa kehamilan sangat ditentukan oleh usia seseorang, umur terlalu muda atau kurang dari 20 tahun dan umur lanjut labih dari 35 tahun merupakan kehamilan resiko tinggi. Ibu-ibu yang terlalu muda seringkali secara emosional dan fisik belum matang, ibu yang masih muda masih tergantung pada orang lain. Secara teori Partus Abnormal lebih tinggi pada ibu-ibu muda berusia kurang dari 20 tahun. Faktor usia ibu bukanlah faktor utama kelahiran Partus Abnormal, tetapi kelahiran Partus Abnormal tampak meningkat pada wanita yang berusia di luar usia 20 sampai 35 tahun. Pada usia $>35$ tahun masih banyak yang bisa melahirkan normal ini dikarenakan ibu-ibu sudah banyak yang bekerja dan mereka memilih menikah pada usia menjelang 30 tahun, mereka juga sudah banyak mengerti tentang proses persalinan dengan melihat pengalaman dan banyak membaca buku.

Umur Ibu merupakan salah satu faktor untuk melahirkan partus Abnormal. Umur yang dianggap beresiko adalah $<20$ tahun dan $>35$ tahun. Pada $<20$ tahun fungsi dari alat reproduksinya belum matang sehingga menggangu perkembangan janin. Pada usia $>35$ tahun terjadi degenerasi fungsi alat reproduksinya sehingga dapat menyebabkan terjadinya gangguan pada janin (Winjaksastro, 2006).

\section{Pendidikan Ibu}

Tingkat pendidikan seorang ibu akan sangat berpengaruh dalam penerimaan informasi yang diterima. Ibu dengan pendidikan yang cukup akan melakukan hal-hal yang diperlukan oleh bayi. Misalnya kesadaran untuk memenuhi gizi, imunisasi, pemeriksaan berkala (antenatal care). Sebaliknya pendidikan yang rendah akan sulit bagi seorang ibu untuk menerima inovasi dan sebagian besar kurang mampu menciptakan kebahagiaan dalam keluarganya, selain itu kurang menyadari betapa pentingnya perawatan sebelum melahirkan.

Pemerintah telah berupaya untuk meningkatkan pengetahuan ibu hamil melalui program kesehatan ibu dan anak, penyuluhan-penyuluhan kesehatan selama ibu hamil.

\section{Tekanan Darah}

Hipertensi pada kehamilan sering dikenal sebagai preeklamsi juga merupakan indikasi partus abnormal karena akan terjadi eklamsi (kejang-kejang) pada waktu persalinan. Apabila terjadi hipertensi pada waktu persalinan ini merupakan indikasi untuk mempercepat persalinan. Dari hasil penelitian didapat hasilnya terbalik lebih banyak yang PEB melahirkan normal kemungkinan hal ini dikarenakan rata-rata pasien yang datang ke RS banyak pasien rujukan dari luar kota dan saat diruangan sudah pembukaan lengkap yaitu kala II jadi sudah bisa dilahirkan segera dan PEBnya masih golongan PEB ringan, jika Eklamsi pasien harus segera dilakukan tindakan SC setelah kondisi pasien stabil.

Tabel 1

Analisis Bivariat

\begin{tabular}{|c|c|c|c|c|c|c|}
\hline \multirow{3}{*}{ Variabel } & \multicolumn{4}{|c|}{ Persalinan } & \multirow{3}{*}{ (p Value) } & \multirow{3}{*}{$\begin{array}{l}\text { OR/ } \\
\text { (CI 95\%) }\end{array}$} \\
\hline & \multicolumn{2}{|c|}{$\begin{array}{l}\text { Kasus } \\
\text { (Abnormal) }\end{array}$} & \multicolumn{2}{|c|}{$\begin{array}{l}\text { Kontrol } \\
\text { (Normal) }\end{array}$} & & \\
\hline & $\mathbf{n}$ & $\%$ & $\mathbf{n}$ & $\%$ & & \\
\hline \multicolumn{7}{|l|}{ Kondisi Kehamilan } \\
\hline Beresiko: Kehamilan bermasalah & 121 & 49,4 & 72 & 29,4 & 0,001 & $2,35(1,67-3,40)$ \\
\hline Tdk beresiko : Kehamilan normal & 124 & 50,6 & 173 & 70,6 & & \\
\hline Total & 245 & 100 & 245 & 100 & & \\
\hline \multicolumn{7}{|l|}{ Jarak Kelahiran } \\
\hline Beresiko : $<2 \& \geq 6$ & 131 & 53,5 & 105 & 42,9 & 0,024 & $1,53(1,07-2,18)$ \\
\hline Tdk beresiko : $2-\overline{5}$ & 114 & 46,5 & 140 & 57,1 & & \\
\hline Total & 245 & 100 & 245 & 100 & & \\
\hline \multicolumn{7}{|l|}{ Kadar $\mathbf{H b}$} \\
\hline Beresiko : Anemia < 11 gr \% & 66 & 26,0 & 9 & 3,7 & 0,024 & $9.67(4.69-19.92)$ \\
\hline Tdk beresiko : Tidak Anemia $\geq 11$ gr\% & 179 & 73,1 & 236 & 96,7 & & \\
\hline Total & 245 & 100 & 245 & 100 & & \\
\hline
\end{tabular}




\begin{tabular}{|c|c|c|c|c|c|c|}
\hline \multirow{2}{*}{\multicolumn{7}{|c|}{ Tekanan darah }} \\
\hline Beresiko : Hipertensi & & & & & & \\
\hline Tdk beresiko : Normal & 197 & 80,4 & 164 & 66,9 & & \\
\hline Total & 245 & 100 & 245 & 100 & & \\
\hline \multicolumn{7}{|l|}{ Kondisi Ketuban } \\
\hline Beresiko : Ketuban Pecah Dini & 61 & 24,9 & 33 & 13,5 & 0,002 & $2,1(1,3-3,3)$ \\
\hline Tdk beresiko : Tidak KPD & 184 & 75,1 & 212 & 86,5 & & \\
\hline Total & 245 & 100 & 245 & 100 & & \\
\hline \multicolumn{7}{|l|}{ Tempat Tinggal } \\
\hline Beresiko : Luar Kota & 89 & 36,3 & 47 & 19,2 & 0,001 & $2,49(1,6-3,6)$ \\
\hline Tdk beresiko : Dalam Kota & 156 & 63,7 & 198 & 80,8 & & \\
\hline Total & 245 & 100 & 245 & 100 & & \\
\hline \multicolumn{7}{|l|}{ Cara Datang Ke RS } \\
\hline Beresiko : Rujuk & 115 & 46,9 & 78 & 31,8 & 0,001 & $1,89(1,3-2,7)$ \\
\hline Tdk beresiko : Sendiri & 130 & 53,1 & 167 & 68,2 & & \\
\hline Total & 245 & 100 & 245 & 100 & & \\
\hline \multicolumn{7}{|l|}{ Umur } \\
\hline Beresiko : $<20 \&>35$ tahun & 69 & 28,2 & 46 & 18,8 & 0,019 & $1,69(1,1-2,6)$ \\
\hline Tdk beresiko : 20-35 tahun & 176 & 7,8 & 199 & 81,2 & & \\
\hline Total & 245 & 100 & 245 & 100 & & \\
\hline \multicolumn{7}{|l|}{ Paritas } \\
\hline Beresiko: Paritas $0 \&>4$ & 149 & 60,8 & 121 & 49,2 & 0,014 & $1,59(1,1-2,2)$ \\
\hline Tdk beresiko : Paritas 1-4 & 96 & 39,2 & 124 & 50,6 & & \\
\hline Total & 245 & 100 & 245 & 100 & & \\
\hline \multicolumn{7}{|l|}{ Pekerjaan } \\
\hline Beresiko : bekerja & 114 & 46,5 & 77 & 31,4 & 0,001 & $1,89(1,3-2,7)$ \\
\hline Tdk beresiko : tdk bekerja & 131 & 53,5 & 168 & 68,6 & & \\
\hline Total & 245 & 100 & 245 & 100 & & \\
\hline \multicolumn{7}{|l|}{ Pendidikan } \\
\hline Beresiko : tdk sekolah, SD, SMP & 150 & 61,2 & 119 & 48,6 & & \\
\hline Tdk beresiko : SMA \& PT & 95 & 38,8 & 126 & 51,4 & 0,006 & $1,67(1,2-2,4)$ \\
\hline Total & 245 & 100 & 245 & 100 & & \\
\hline
\end{tabular}

Tabel 2

Analisis Multtivariat faktor resiko Partus Abnormal

\begin{tabular}{lllll}
\hline Variabel & P value & OR & & \multicolumn{2}{c}{$95 \%$ CI. For EXP (B) } \\
\cline { 4 - 5 } & & & Lower & Upper \\
\hline Kondisi Kehamilan & 0.000 & 2.767 & 1.663 & 4.60 \\
Kadar Hb & 0.000 & 9.594 & 4.263 & 21.59 \\
Tekanan Darah & 0.000 & 0.170 & 0.094 & 0.31 \\
Tempat Tinggal & 0.009 & 1.936 & 1.182 & 3.17 \\
Cara Datang ke RS & 0.000 & 2.863 & 1.783 & 4.60 \\
Umur & 0.007 & 2.11 & 1.206 & 3.32 \\
Pekerjaan & 0.000 & 3.00 & 1.886 & 4.78 \\
Pendidikan & 0.023 & 1.697 & 1.074 & 2.68 \\
\hline
\end{tabular}

\section{KESIMPULAN}

Faktor kadar $\mathrm{Hb}$ yang memiliki $\mathrm{Hb}<11$ gr\% lebih beresiko melahirkan bayi dengan Partus Abnormal 9,59 kali dibandingkan ibu yang memiliki $\mathrm{Hb}>11 \mathrm{gr} \%$. Faktor pekerjaan lebih beresiko dengan Partus Abnormal 3 kali dibandingkan ibu yang tidak bekerja. Faktor Cara datang ke Rs dengan rujukan lebih beresiko dengan Partus Abnormal 2,86 kali dibandingkan ibu dengan cara datang ke RS dengan sendiri. Faktor kondisi kehamilan bermasalah lebih beresiko dengan Partus Abnormal 2,76 kali dibandingkan ibu yang memiliki kondisi kehamilan normal. Faktor umur $<20$ tahun dan umur $>35$ tahun lebih beresiko dengan Partus Abnormal 2,11 kali dibandingkan ibu yang umur 20 tahun sampai dengan umur 35 tahun. Faktor tempat tinggal di luar kota lebih beresiko dengan Partus Abnormal 1,93 kali dibandingkan ibu dengan tempat tinggal dalam kota. Faktor pendidikannya SD dan SMP lebih beresiko melahirkan bayi dengan Partus Abnormal 1,69 kali dibandingkan ibu yang pendidikannya SMA dan PT. Faktor tekanan darah atau hipertensi lebih beresiko melahirkan bayi dengan Partus Abnormal 1,69 kali dibandingkan ibu yang tekanan darahnya normal. 


\section{SARAN}

Diharapkan Bagi RSUD Arifin Achmad Provinsi Riau lebih sering melakukan pemberian informasi secara rutin baik melalui konseling maupun media seperti leaflet, poster dll. Meningkatkan upaya sistem rujukan medis dengan menjalin kerjasama dan komunikasi melalui puskesmas dan klinik bersalin sehingga dapat memberikan pelayanan yang bermutu.

\section{UCAPAN TERIMA KASIH}

Ucapan terima kasih ditujukan kepada Direktur RSUD Arifin Achmad Provinsi Riau, Kepala Ruangan Rekam Medis RSUD Arifin Achmad, Kepala Ruangan Camar I RSUD Arifin Achmad temapat penelitian dilakukan dan Ketua Prodi Pasca Magister STIKes Hang Tuah Pekanbaru Prof. Dr. Dr. Buchari Lapau, MPH yang memberikan masukan dalam penelitian ini.

\section{DAFTAR PUSTAKA}

Departemen Kesehatan RI, Pelayanan Kesehatan Ibu Hamil Resiko Tinggi, Jakarta, Depkes, 2003

Kusumawati Y, Faktor-faktor risiko yang berpengaruh terhadap Persalinan dengan
Tindakan di RS Moewardi Surakarta tahun 2006. FK Undip. Diakses tanggal 1 Desember 2010

Rusydi,S.D., Partus Kasep di RSUP Palembang selama 5 tahun (1 Januari 2000 - 31 Desember 2004), Jurnal Kedokteran dan Kesehatan, April 2005, vol. 37 no.2; p:1005-1008.

Rusydi, S.D., Tindakan Ekstraksi Vakum dan Forsen di Departemen Obstetri dan Ginekologi dan RS Dr. Mohammad Hoesin Palembang selama 5 Tahun (periode Agustus 1999-Juli 2004), Jurnal Kedokteran dan Kesehatan, April 2005, Th 37 No.2; p:966-970.

SDKI, Biro Pusat Statistik, BKKBN, Departemen Kesehatan., 2007, Survei Demografi dan Kesehatan Indonesia, Jakarta.

Senewe, FP dan Sulistyowati, N. Faktor-faktor yang Berhubungan dengan Komplikasi Persalinan Tiga Tahun Terakhir di Indonesia (Analisis Lanjutan SKRT - Surkesnas 2001), Buletin Penelitian Kesehatan, 2004, vol. 43 no. 2

Taber, B., Kapita Selekta Kedaruratan Obstetri dan Ginekologi (Alih Bahasa Supriyadi, T. Dan Gunawan, J.), Jakarta, EGC, 2002. 